Zeszyty Naukowe Szkoły Głównej Gospodarstwa Wiejskiego w Warszawie Problemy Rolnictwa Światowego tom 17 (XXXII), zeszyt 1, 2017: 95-105

DOI: $10.22630 /$ PRS.2017.17.1.9

Małgorzata Kosicka-Gębska $^{1}$, Jerzy Gębski' ${ }^{2}$, Katarzyna Kwiecińska ${ }^{3}$, Agnieszka Tul-Krzyszczuk ${ }^{4}$, Maria Jeznach ${ }^{5}$

Szkoła Główna Gospodarstwa Wiejskiego w Warszawie

\title{
Charakterystyka porównawcza zachowań nabywczych polskich konsumentów mięsa na tle porównań międzynarodowych
}

\section{Comparative Characteristics of the Purchasing Behavior of Polish Consumers of Meat on the Background of International Comparisons}

\begin{abstract}
Synopsis. Mięso jest jednym z podstawowych produktów żywnościowych, który we współczesnych czasach wzbudza wiele kontrowersji. $Z$ jednej strony docenia się jego walory odżywcze, a szczególnie zawartość pełnowartościowego białka, związków mineralnych i witamin. $Z$ drugiej strony uważa się, że jego nadmierne spożycie może przyczynić się do powstawania chorób cywilizacyjnych. Celem artykułu była analiza zachowań nabywczych polskich konsumentów mięsa świeżego ogółem, mięsa wieprzowego, drobiowego i wołowego w Polsce na tle wybranych przykładów pochodzących z innych krajów. Szczególną uwagę zwrócono na wybór miejsca zakupu, ocenę częstotliwości nabywania, a także na czynniki determinujące wybór poszczególnych rodzajów mięs przez konsumentów. Oceniono również wpływ producenta na podejmowanie decyzji przez konsumentów o zakupie mięsa. Stwierdzono, że w Polsce, niezależnie od rodzaju mięsa, wzrasta popularność specjalistycznych sklepów mięsnych, czego nie odnotowuje się w innych krajach. Przeprowadzona analiza asocjacji dowiodła, że polscy konsumenci podejmując decyzje o nabyciu mięsa zwracają przede wszystkim uwagę na jego cenę, wygląd ogólny oraz barwę.
\end{abstract}

Slowa kluczowe: mięso, wieprzowina, wołowina, drób, zachowania konsumenckie, miejsce zakupu

\begin{abstract}
Meat is one of the basic foodstuffs, which in modern times arouses a lot of controversy. On the one hand, appreciates its nutritional values, especially the content high in protein, minerals and vitamins. On the other hand, it is considered that the excessive intake can contribute to the formation of civilization diseases. The aim of the article was to analyze the purchasing behavior of Polish consumers of fresh meat in general and pork, poultry and beef. Particular attention was paid to the choice of the place of purchase, the evaluation of the frequency of purchase, as well as the factors determining the choice of different types of meat by consumers. Also evaluated the impact of the manufacturer's decision-making by consumers purchase meat. It was found that regardless of the type of meat, increases the importance of specialist butcher shops. The analysis of association proved that consumers are making decisions about the purchase of meat draw attention primarily on its price, overall appearance and color.
\end{abstract}

Key words: fresh meat, pork, beef, poultry, consumer behavior, place of purchase

\footnotetext{
${ }^{1}$ dr hab., Katedra Organizacji i Ekonomiki Konsumpcji SGGW w Warszawie, ul. Nowoursynowska 159c, 02-776 Warszawa, e-mail: malgorzata_kosicka_gebska@sggw.pl

${ }^{2}$ dr inż., Katedra Organizacji i Ekonomiki Konsumpcji SGGW w Warszawie, ul. Nowoursynowska 159c, 02-776 Warszawa, e-mail: jerzy_gebski@sggw.pl

${ }^{3}$ mgr inż., Katedra Organizacji i Ekonomiki Konsumpcji SGGW w Warszawie, ul. Nowoursynowska 159c, 02-776 Warszawa, e-mail: katarzyna_kwiecinska@sggw.pl

${ }^{4}$ dr inż., Katedra Organizacji i Ekonomiki Konsumpcji SGGW w Warszawie, ul. Nowoursynowska 159c, 02-776-Warszawa, e-mail: agnieszka_tul_krzyszczuk@sggw.pl

${ }^{5}$ dr hab., Katedra Organizacji i Ekonomiki Konsumpcji SGGW w Warszawie, ul. Nowoursynowska 159c, 02-776 Warszawa, e-mail: maria_jeznach@sggw.pl
} 


\section{Wprowadzenie}

Zachowania konsumentów stanowią kompleks działań i czynności mających na celu zaspokojenie potrzeb człowieka przez zdobywanie dóbr i usług według odczuwanego systemu potrzeb i preferencji (Niewczas, 2013). Zmieniają się one pod wpływem wielu czynników, do których można zaliczyć m.in.: rozwój gospodarczy, zmiany polityczne, zmiany zamożności społeczeństwa, globalizację (Garbarski, 2001; Żelazna i in., 2002; Szwacka, 2006; Szwacka-Salmonowicz, 2003) jako uwarunkowania zachowań konsumentów wymienia czynniki ekonomiczne, społeczne, psychologiczne i marketingowe. Dodaje, że waga i znaczenie poszczególnych z nich są ściśle powiązane $\mathrm{z}$ charakterem produktów zaspokajających potrzeby żywnościowe.

Istotną rolę $\mathrm{w}$ zachowaniach konsumentów odgrywają zachowania związane z nabywaniem produktu, zwane nabywczymi. Istniejący stan nierównowagi na rynku żywności wynikający z nadwyżki podaży nad popytem i chęć konkurowania podmiotów na rynku, zmusza producentów i handlowców do poszukiwania informacji na temat zachowań nabywczych konsumentów związanych $\mathrm{z}$ wyborem miejsca dokonywania zakupów żywności i czynników warunkujących podejmowanie decyzji.

Zdaniem Gutkowskiej i Ozimek (2005) konsumenci decydują się na zakup żywności ze względu na: kulturę, zwłaszcza zwyczaje, tradycję, religię, presję społeczną, dostępność produktów na rynku, walory użytkowe, aspekty ekonomiczne (cena i związany z nią ekwiwalent korzyści, dochód konsumenta), charakterystykę żywieniową produktu, działania promocyjne, przyzwyczajenie. Wiele badań podkreśla, że istotnym czynnikiem decydującym o zakupie produktu żywnościowego jest jego marka (Górska-Warsewicz i Pałaszewska-Reindl, 2006; Kosicka-Gębska i in., 2011; Philipsen i Kolind, 2012). Przy czym warto zauważyć, że decyzje nabywcze dotyczące produktów żywnościowych w większości podejmowane są szybko, bez namysłu (Rudnicki, 2000). Kupujący kierują się przede wszystkim nawykami i rutyną. Jednak niektóre decyzje, dotyczące zwłaszcza produktów kupowanych po raz pierwszy, droższych, należą do działań rozważnych. Badania dowodzą, że podczas zakupów żywności polscy konsumenci zwracają uwage przede wszystkim na cenę, datę przydatności do spożycia, skład produktu, markę i wartość odżywczą (Krasnowska i Salejda, 2011).

Rynek produktów żywnościowych pochodzenia zwierzęcego jest jednym z głównych segmentów gospodarki żywnościowej na świecie, w tym także w Polsce. Globalna produkcja zwierzęca wykazuje wzrostową tendencję, co jest wynikiem rosnącego popytu na produkty pochodzenia zwierzęcego, w tym mięsa i jego przetworów (Kwasek, 2013).

Zwracając uwage na zmiany w spożyciu poszczególnych rodzajów mięsa przez Polaków w okresie 1990-2014, na podstawie analiz rynkowych przedstawionych w opracowaniu „Rynek mięsa - stan i perspektywy (2015) można stwierdzić, że nastapił wzrost poziomu spożycia mięsa ogółem, a w szczególności mięsa wieprzowego z 37,7 kg na mieszkańca do 39,1 kg na mieszkańca i drobiowego z 7,6 kg na mieszkańca do 28,2 kg na mieszkańca. Ograniczono spożywanie mięsa wołowego z 16,4 kg na mieszkańca do 1,6 kg na mieszkańca, co ma także miejsce w wielu krajach Unii Europejskiej (Campo, 2006).

Mięso stanowi istotny element codziennej diety większości ludzi na świecie. Jest produktem złożonym, zawierającym wiele różnorodnych związków chemicznych określających m.in. jego wartość odżywczą. Walory zdrowotne mięsa od dawna są przedmiotem kontrowersyjnych poglądów dietetyków. Jedni widzą w mięsie znakomite źródło niezbędnych składników odżywczych, inni natomiast przypisują mięsu 
odpowiedzialność za występowanie chorób cywilizacyjnych (Cross i in., 2010). W przypadku mięsa drobiowego dietetycy i lekarze zwracają uwagę na jego korzystną wartość odżywczą (Kołożyn-Krajewska i Sikora, 2004; Rachwał, 2006). Istotny jest również łatwy i szybki sposób jego przygotowania oraz niska cena w porównaniu z innymi rodzajami mięs (Verbake i Viaene, 1999; McAfee i in., 2010; Radziukiewicz, 2012). Niektóre badania dowodzą, że mięso czerwone, do którego zalicza się wołowinę i wieprzowinę zawiera zbyt duże ilości tłuszczu, a szczególnie jego frakcji LDL, mogącej przyczyniać się do powstawania otyłości, chorób układu krążenia,, alergii, czy różnych odmian nowotworów (Cross i in., 2010; Santarelli i in., 2010). Żywieniowcy zalecają, by białe mięso jadać $2-3$ razy w tygodniu, a czerwone tylko kilka razy w miesiącu. Zalecana tygodniowa porcja zjadanego mięsa przez dorosłą osobę nie powinna być większa niż $0,5 \mathrm{~kg}$.

Celem artykułu była analiza zachowań nabywczych polskich konsumentów mięsa świeżego ogółem, mięsa wieprzowego, drobiowego i wołowego w Polsce na tle wybranych porównań pochodzących z innych krajów. Szczególną uwagę zwrócono na wybór miejsca zakupu, ocenę częstotliwości nabywania oraz na czynniki determinujące wybór poszczególnych rodzajów mięs przez konsumentów. Oceniono także wpływ producenta na podejmowanie decyzji przez konsumentów o zakupie mięsa.

\section{Analiza danych i metody badawcze}

Dane do opracowania artykułu pochodziły z ogólnopolskiego badania internetowego przeprowadzonego w 2015 roku na próbie 1000 konsumentów deklarujących, że są konsumentami mięsa. Badanie miało charakter ilościowy, a dobór próby był celowy. Zastosowanym narzędziem badawczym był autorski kwestionariusz ankiety o wysokim stopniu standaryzacji. Łącznie składał się on z 32 pytań podstawowych i 10 pytań metryczkowych. Charakterystykę próby badawczej przedstawia tabela 1. Badanie właściwe zostało poprzedzone badaniem pilotażowym wykonanym z 37 konsumentami w celu sprawdzenia poprawności kwestionariusza i doprecyzowania pytań.

Analizy statystyczne danych empirycznych przeprowadzono z wykorzystaniem pakietu statystycznego SAS 9.4. Ocenę związku pomiędzy częstotliwością nabywania mięsa a cechami socjodemograficznymi charakteryzującymi respondentów wykonano na podstawie tabel kontyngencji, a zależności istotne statystycznie stwierdzono na podstawie testu chi $^{2}$ przy $\mathrm{p}<0,05$, a siłę związku oceniono na podstawie współczynnika korelacji V-Cramera. Wybór najistotniejszych czynników wpływających na decyzję o zakupie mięsa dokonany został na podstawie analizy asocjacji z wykorzystaniem SAS Enterprise Miner 14.1. 
Tabela 1. Charakterystyka badanej populacji

Table 1. Characteristics of population

\begin{tabular}{|c|c|c|}
\hline \multirow{2}{*}{ Wyszczególnienie } & \multicolumn{2}{|c|}{ Populacja ogółem } \\
\hline & $\mathrm{N}$ & $\%$ \\
\hline \multicolumn{3}{|l|}{ Płeć } \\
\hline kobieta & 527 & 52,7 \\
\hline mężczyzna & 473 & 47,3 \\
\hline \multicolumn{3}{|l|}{ Wiek } \\
\hline do 20 lat & 121 & 12,1 \\
\hline 21-30 lat & 268 & 26,8 \\
\hline $31-40$ lat & 199 & 19,9 \\
\hline 41-50 lat & 147 & 14,7 \\
\hline $51-60$ lat & 145 & 14,5 \\
\hline pow. 60 lat & 117 & 11,7 \\
\hline \multicolumn{3}{|l|}{ Wykształcenie } \\
\hline podstawowe & 175 & 17,5 \\
\hline zawodowe & 236 & 23,6 \\
\hline średnie & 396 & 39,6 \\
\hline wyższe & 193 & 19,3 \\
\hline \multicolumn{3}{|l|}{ Opinia o dochodzie rodziny: } \\
\hline jest w ogóle niewystarczający & 69 & 6,9 \\
\hline zaspokaja tylko podstawowe potrzeby & 250 & 25 \\
\hline nie pozwala na wszystkie wydatki & 456 & 45,6 \\
\hline stać nas na wszystko & 163 & 16,3 \\
\hline stać nas na wszystko i dodatkowo możemy zaoszczędzić & 62 & 6,2 \\
\hline \multicolumn{3}{|l|}{ Miejsce zamieszkania } \\
\hline miasto pow. 500 tys. & 184 & 18,4 \\
\hline miasto poniżej 500 tys. & 481 & 48,1 \\
\hline Wieś & 335 & 33,5 \\
\hline
\end{tabular}

Źródło: badanie własne.

\section{Wyniki badań}

Analiza zgromadzonego materiału badawczego pozwala na stwierdzenie, że polscy konsumenci są częstymi nabywcami mięsa świeżego ogółem o czym świadczą odpowiedzi prawie $1 / 2$ respondentów $(46,1 \%$ ), deklarujących jego kupowanie z częstotliwością kilku razy $\mathrm{w}$ tygodniu, a co piątego badanego $-\mathrm{z}$ częstotliwością raz $\mathrm{w}$ tygodniu $(21,6 \%)$. Co dziesiąty konsument przyznaje się do codziennego zakupu mięsa $(12,2 \%)$. Zwracając uwagę na zakup poszczególnych rodzajów mięsa zauważono, iż najczęściej kupowanymi rodzajem mięsa było mięso drobiowe oraz mięso wieprzowe, co jest zgodne $\mathrm{z}$ danymi statystycznymi przedstawionymi w raporcie Rynek mięsa - stan i perspektywy (2015). W przypadku wołowiny, około $20 \%$ badanych kupowało ją zaledwie kilka razy w roku, a co piętnasty badany nie nabywał jej wcale.

Jak dowodzą badania GfK PGD, mięso świeże i wędliny są trzecią najczęściej spożywaną kategorią produktów spożywczych przez Polaków. Polscy konsumenci najczęściej wybierają gotowe wędliny (w 2014 r. średnia miesięczna częstotliwość spożycia wędlin osiagnęła rekord i wyniosła prawie 18 razy w miesiącu). Często sięgają także po drób (średnio 9,4 raza na miesiąc) oraz wieprzowinę (7,1 razy w miesiącu) (Zmiany preferencji..., 2015). W przypadku konsumentów z innych krajów zaobserwowano, że Niemcy nadal deklarują swoje przywiązanie do mięsa wieprzowego i mały udział 
w codziennej diecie mięsa wołowego. Zaledwie $40 \%$ respondentów spożywało wołowinę co najmniej raz w tygodniu, a niemal $30 \%$ badanych stwierdziło, że nigdy nie jadło mięsa wołowego (Becker i in., 2000). W odróżnieniu do konsumentów z Polski, amerykańscy konsumenci, według badań Guenther i in. (2005) spożywali wołowinę dość często, bowiem 2/3 mężczyzn i więcej niż połowa kobiet (54\%) jadło mięso wołowe przynajmniej raz w tygodniu, przy jednoczesnych deklaracjach zamiaru ograniczenia poziomu spożywania wołowiny na korzyść mięsa drobiowego. Jeszcze wyższą deklarowaną częstotliwością spożywania mięsa wołowego wykazywali się muzułmańscy konsumenci mieszkający w Belgii. Bowiem według wyników badania jakościowego, 31,0\% badanych deklarowało spożywanie wołowiny z częstotliwością 1-2 razy w tygodniu (Bonne i Verbeke, 2006).

Spośród cech socjodemograficznych dochód wyrażony subiektywną opinią badanych, wykazywał statystycznie istotną zależność z częstotliwością kupowania mięsa świeżego ogółem, jak również trzech rodzajów mięs najczęściej spożywanych przez Polaków (tab. 2). Najwyższy poziom korelacji odnotowano w przypadku zależności wpływu dochodu na częstotliwość kupowania mięsa wołowego. Badani kupujący mięso kilka razy w tygodniu stwierdzali, że posiadany dochód jest niewystarczający i pozwala na zaspokojenie tylko podstawowych potrzeb realizowanych w gospodarstwie domowym.

Według międzynarodowego raportu Nielsena z 2013 roku czynnik finansowy jest wciąż istotny dla Polaków dokonujących zakupów żywności, w tym mięsa, a mniej ważny dla przeciętnego kupującego Europejczyka, który zwraca uwage przede wszystkim na świeżość produktów, wygodę oraz oszczędność czasu (Gdzie Polacy..., 2013).

Tabela 2. Charakterystyka współczynnika korelacji V-Cramera obrazującego siłę związku pomiędzy częstotliwością nabywania mięsa a cechami socjodemograficznymi charakteryzującymi respondentów

Table 2. Characterization of V-Cramer correlation coefficient to determine the relationship between the frequency of meat acquisition and sociodemographic characteristics of respondents

\begin{tabular}{l|ccccc}
\hline \multirow{2}{*}{ Rodzaj mięsa } & \multicolumn{5}{c}{ Cechy socjodemograficzne } \\
& płeć & wiek & wykształcenie & $\begin{array}{c}\text { opinia } \\
\text { o dochodzie }\end{array}$ & $\begin{array}{c}\text { miejsce } \\
\text { zamieszkania }\end{array}$ \\
\hline ogółem & 0,0976 & 0,0761 & 0,0830 & $0,1523^{*}$ & 0,0902 \\
wieprzowe & 0,0936 & 0,0840 & 0,0651 & $0,1321^{*}$ & 0,0669 \\
wołowe & 0,0938 & $0,1066^{*}$ & 0,0574 & $0,1946^{*}$ & 0,0745 \\
drobiowe & 0,0384 & 0,0746 & 0,0879 & $0,1532^{*}$ & $0,1476^{*}$ \\
\hline
\end{tabular}

*istotne statystycznie przy $p<0,05$

Źródło: badanie własne.

Częstotliwość zakupu mięsa drobiowego była ponadto istotnie statystycznie skorelowana $\mathrm{z}$ miejscem zamieszkania respondentów. Ten rodzaj mięsa był nabywany $\mathrm{z}$ częstotliwością kilku razy $\mathrm{w}$ tygodniu oraz codziennie przez badanych pochodzących z miast posiadających mniej niż 500 tys. mieszkańców. Najrzadziej mięso drobiowe kupowali mieszkańcy wsi z częstotliwością kilku razy w miesiącu $(31,3 \%)$.

W dobie globalizacji oraz kryzysu gospodarczego, rozwoju nowoczesnych technologii informacyjno-komunikacyjnych i nasilającej się konkurencji w handlu, obserwuje się wielość postaw, stylów życia i różnicowanie się zachowań konsumenckich dotyczących wyboru miejsca zakupu żywności (Kłosiewicz-Górecka, 2013). W obecnych czasach 
nabywając produkty żywnościowe, w tym mięso, konsumenci mają możliwość ich wyboru w wielu rodzajach placówek handlowych. Zmienia się struktura branżowa sklepów z artykułami żywnościowymi. Maleje liczba sklepów ogólnospożywczych, a wzrasta sklepów o specjalizacji branżowej: mięsnych, owocowo-warzywnych, piekarniczociastkarskich i z napojami alkoholowymi. Potwierdzają to również badania firmy Market Side. Według nich, ponad 2/3 Polaków regularne kupuje w sklepach specjalistycznych. Największym zainteresowaniem konsumentów cieszą się sklepy piekarnicze, które odwiedzało regularnie $38 \%$ badanych konsumentów, oraz mięsne - 36\% konsumentów. Cenione są one przede wszystkim za świeżość produktów oraz możliwość zakupu artykułów, których nie ma w ofercie sklepów ogólnospożywczych (Sklepy specjalistyczne..., 2012, s. 20). Także dane pochodzące z międzynarodowego raportu Nielsena z 2013 roku dowodzą, że w przeciwieństwie do innych krajów europejskich, w Polsce zakupu świeżej żywności najczęściej dokonuje się nie w supermarketach, ale w sklepach specjalistycznych. Według nich, co trzeci Polak kupuje mięso i drób w sklepie mięsnym. Około $20 \%$ badanych wybiera supermarket, $14 \%$ - dyskont, a $10 \%$ - hipermarket. Zaledwie $8 \%$ respondentów kupuje produkty tego rodzaju w pobliskim sklepie spożywczym. Z badania Kosickiej-Gębskiej (2013) wynika, że najczęściej wskazywanym przez respondentów miejscem zakupu mięsa wołowego był sklep mięsny $(55,5 \%)$. Wieprzowinę i drób kupowano natomiast częściej w supermarketach (odpowiednio: 22,0\% i $29,2 \%$ ). Dla porównania, statystyczny Europejczyk, zdecydowanie opowiadał się za zakupami mięsa $\mathrm{w}$ supermarkecie, a sklepy specjalistyczne wybierała mniej niż $1 / 5$ klientów (Gdzie Polacy..., 2013). Zwracając uwagę na wybór miejsca zakupu każdego rodzaju mięsa przez Niemców można zauważyć, że już od początku lat 90 . zmniejszał się udział konsumentów kupujących mięso w sklepach mięsnych. Stanowiły one około $30 \%$ całej sprzedaży produktów mięsnych. Zaś hiper- i supermarkety generowały około $40 \%$ sprzedaży, a sklepy dyskontowe $-25 \%$ (Becker i in., 2000).

Opisane wyżej tendencje znalazły potwierdzenie także w wynikach badania empirycznego. Dowiedziono w nim, że niezależnie od rodzaju mięsa, najczęściej kupowano je w tzw. sklepach mięsnych (rys. 1), czyli w sklepach specjalistycznych, które są często sklepami firmowymi. W popularnych od kilku lat w Polsce sklepach dyskontowych stosunkowo rzadko kupowano mięso. Przede wszystkim było to mięso wołowe i drobiowe, które w tego typu sklepach oferuje się w formie pakowanej i porcjowanej.

Stwierdzono, że polscy konsumenci nabywając mięso wykazują się przywiązaniem do jego producentów/marek. Według badanych, firmą najbardziej godną zaufania jest Sokołów. Ponad $2 / 5$ badanych deklarowało zakup mięsa pochodzącego od tego producenta. $\mathrm{Na}$ kolejnych miejscach wymieniano Morliny $(20,5 \%)$, Łuków $(17,6 \%)$ oraz Wierzejki $(12,5 \%)$. W przypadku analizy wpływu cech socjodemograficznych na wybór preferowanego przez badanych producenta mięsa nie stwierdzono występowania statystycznie istotnych zależności. Wyniki te znalazły swoje potwierdzenie w badaniach Kosickiej-Gębskiej (2013). 


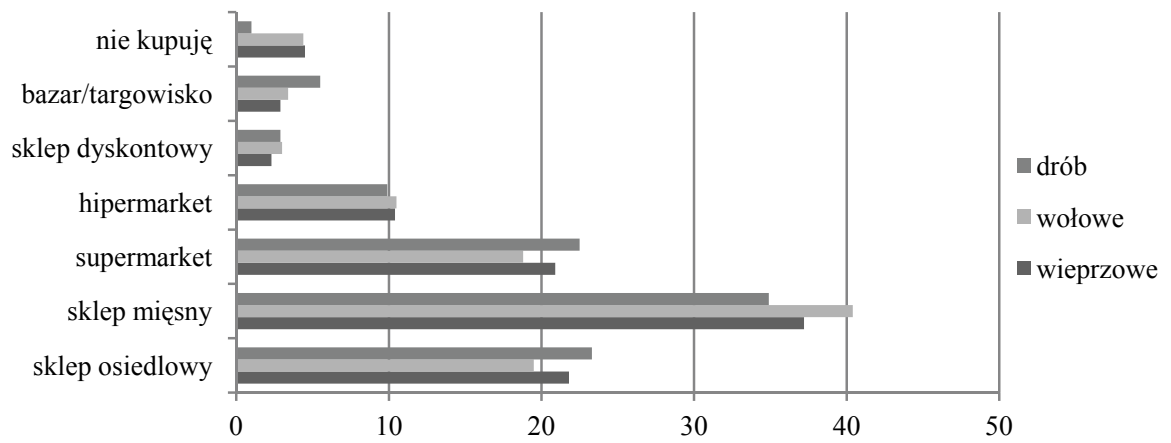

Rys. 1. Preferencje polskich konsumentów związane z wyborem miejsca zakupu mięsa [\%]

Fig. 1. The Polish consumers preferences connected with the choice of place of meat buy [\%]

Źródło: badanie własne.

Proces podejmowania decyzji nabywczych przez konsumentów, jak wykazano we wprowadzeniu do niniejszego artykułu, może być implikowany wieloma czynnikami. Na podstawie analizy zgromadzonych danych statystycznych poddanych analizie asocjacji dowiedziono, że konsumenci mięsa dokonując jego wyboru zwracają przede wszystkim uwagę na trzy czynniki: cenę, wygląd ogólny oraz barwę (rys. 2). Wyniki te potwierdzono w wielu badaniach. I tak, badanie Kosickiej-Gębskiej (2013) obrazujące wpływ wielu czynników na podjęcie decyzji przez konsumentów o zakupie wołowiny dowiodło, że respondenci zwracali przede wszystkim uwagę na wygląd ogólny mięsa $(31,7 \%)$, jego cenę $(30,5 \%)$ oraz barwę $(9,3 \%)$.

Dane uzyskane w badaniu realizowanym przez GfK PDG dowodzą, że szczególnie cena oferowanego produktu, jest najważniejszym kryterium branym pod uwage przy podejmowaniu decyzji o nabywaniu żywności. Przy wyborze produktów mięsnych największe znaczenie ma niska cena. Dotyczy to zarówno świeżego mięsa, jak i wędlin. To kryterium jest kluczowe dla co drugiego respondenta nabywającego oba produkty. Jak wynika $\mathrm{z}$ badania, im starsi konsumenci, tym czynnik ten nabiera większego znaczenia. $\mathrm{Na}$ kolejnym miejscu istotnymi czynnikami dla konsumenta była informacja o tym, że mięso jest wyprodukowane w Polsce, a także istotne znaczenie miał atrakcyjny wygląd kupowanego produktu (Zmiany preferencji..., 2015). Ogólny wygląd produktu to jeden z ważniejszych czynników warunkujących konsumencką ocenę mięsa i podjęcie decyzji o jego nabywaniu, co zostało również potwierdzone $\mathrm{w}$ badaniach międzynarodowych (Grunert i in., 2004; Verbeke, 2008; Wezemael i in., 2011). Podczas dokonywania zakupu konsument zwraca szczególną uwagę na świeżość mięsa, która oceniana jest po jego wyglądzie zewnętrznym (McCarthy i in., 2003). Ocena wizualna mięsa decyduje o jego zakupie lub niekupowaniu. Odbywa się najczęściej przez ocenę barwy mięsa, która dla nabywców jest podstawowym wskaźnikiem świeżości mięsa (Gutkowska i in., 2012). 


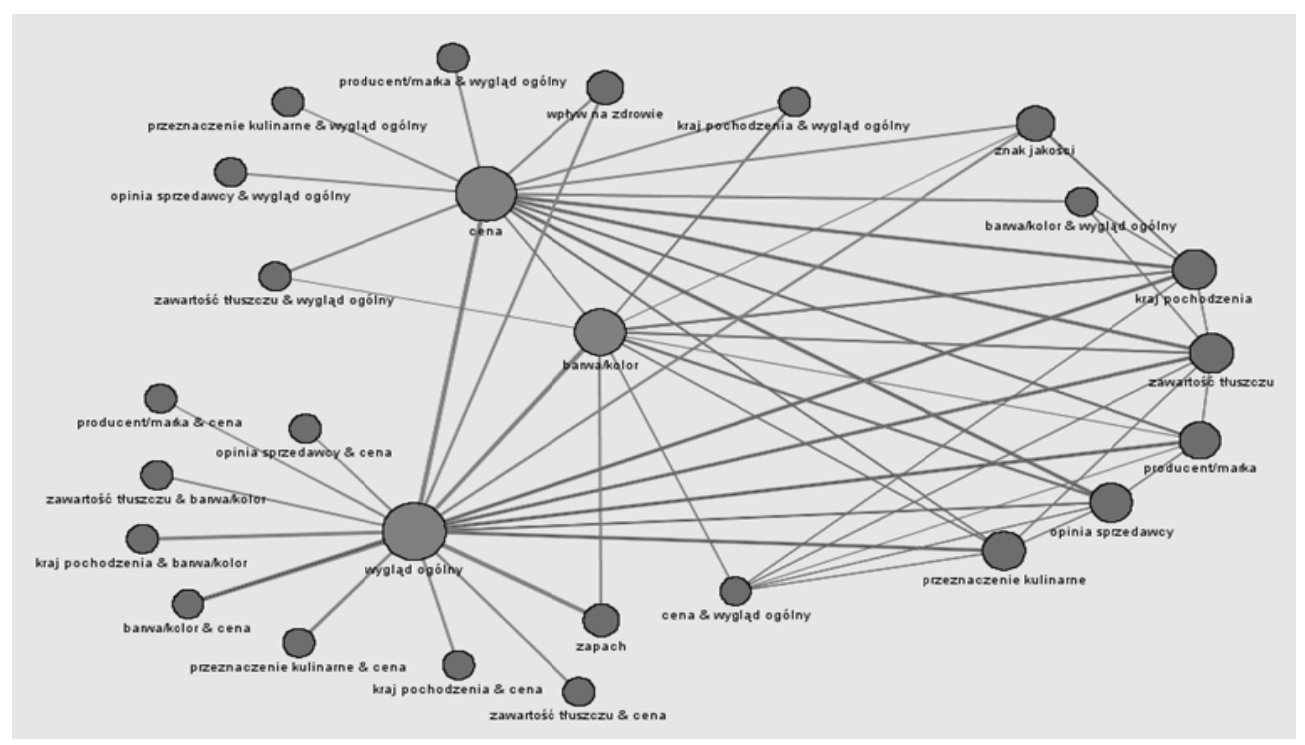

Rys. 2. Wykres asocjacji dla 3 cech mięsa wieprzowego w opinii respondentów

Fig. 2. Association figure for 3 characteristic features of pig meat in respondents' opinion

Źródło: badanie własne.

Inne badania dowiodły, że dla współczesnych konsumentów istotny wpływ na proces podejmowania decyzji o zakupie mięsa ma wiedza konsumentów o jego działaniu na zdrowie człowieka (Verbeke, 2006), a w szczególności wpływ ten kojarzony jest z zawartością składników odżywczych (Cotton i in., 2004) i zawartością tłuszczu. W przypadku tego ostatniego dowiedziono, że konsumenci są coraz mniej skłonni do zakupu wołowiny charakteryzującej się szczególnie nadmiarem thuszczu zewnętrznego, a jego wygląd kojarzy im się z produktem mało zdrowym (Cross i in., 2010; Siriamornpun $\mathrm{i}$ in., 2005). Ponadto za mięso z mniejszą ilością tłuszczu konsumenci byliby skłonni płacić więcej (Cross i in., 2010). Także dla niemieckich konsumentów poziom otłuszczenia był istotnym czynnikiem branym pod uwage podczas zakupu mięsa. Zwracano również uwage na cechy, takie jak: zapach, kruchość, soczystość oraz barwa (Becker i in., 2000). Hiszpańscy konsumenci dla przykładu częściej zwracali uwagę na inne wyróżniki mięsa. Szczególnie ważna była dla nich marka, informacje umieszczone na opakowaniu oraz region pochodzenia mięsa. Własne doświadczenie związane z przyjemnymi odczuciami po spróbowaniu mięsa w przeszłości oraz możliwość zobaczenia mięsa w miejscu jego sprzedaży (wzrokowa ocena barwy, ogólnego wyglądu) - to czynniki, które w dalszej kolejności przyczyniały się do podjęcia decyzji o zakupie mięsa wołowego przez konsumentów pochodzących z Hiszpanii (Sepúlveda i in., 2008). Dla porównania konsumenci z Portugalii częściej zwracali uwagę na markę, barwę, smak, soczystość oraz świeżość mięsa (Banović i in., 2009). Natomiast dla Szwedów istotne znaczenie przy wyborze mięsa, niezależnie od jego rodzaju, miała informacja o kraju jego pochodzenia. W tym przypadku odnotowano istotne statystycznie zależności wskazujące, że na pochodzenie mięsa świeżego częściej zwracały uwagę kobiety, bowiem to one były odpowiedzialne nie tylko za dokonywanie zakupów, ale również za zdrowie 
i bezpieczeństwo swoich rodzin, oraz konsumenci mający małe dzieci (Hoffmann, 2000). We Francji, za najważniejszy czynnik wpływający na decyzje o zakupie oferowanego mięsa wskazano informację o kraju jego pochodzenia. Marmurkowatość mięsa była istotną cechą dla Niemców, a jego barwa dla Francuzów i Brytyjczyków. Anglicy, podejmując decyzje o zakupie mięsa, częściej od Niemców i Francuzów zwracali uwagę na ich cenę (Roosen $\mathrm{i}$ in., 2001).

\section{Podsumowanie}

Polski rynek zmienia się od dwóch dekad i wciąż pojawiają się na nim nowe trendy. W przypadku zakupów mięsa istotne znaczenie odgrywają tzw. sklepy mięsne, zwane specjalistycznymi, czy branżowymi. To właśnie w nich 40,4\% badanych Polaków kupowało wołowinę, $37,2 \%$ wieprzowinę, a $34,9 \%$ mięso drobiowe. Dla porównania, przeciętny Europejczyk kupuje mięso częściej w supermarkecie, a sklepy specjalistyczne wybiera mniej niż $1 / 5$ klientów.

Choć cena jest wciąż jednym $\mathrm{z}$ ważniejszych kryteriów branych pod uwage podczas podejmowania decyzji o zakupie mięsa, to coraz więcej konsumentów zwraca uwagę na wygląd ogólny oraz barwę mięsa. Współczesny konsument oczekuje ponadto od kupowanego produktu odpowiedniej jakości i świeżości. Jest ponadto przywiązany do producentów mięsa, którzy prawdopodobnie są gwarantami spełniającymi wymogi nabywcy względem kupowanego mięsa.

\section{Literatura}

Banović, M., Grunert, K.G, Barreira, M.M., Fontes, M.A. (2009). Beef quality perception at the point of purchase: A study from Portugal. Food Quality and Preference, 20, 4, 335-342.

Becker, T., Benner, E., Glitsch, K. (2000). Consumer perception of fresh meat quality in Germany, British Food Journal, 102, 3, 246-266.

Bonne, K., Verbeke, W. (2006). Muslim consumer's motivations towards meat consumption in Belgium: Qualitative exploratory insights from means-end chain analysis. Anthropology of Food, 5, 2-24.

Campo, M.M., Nute, G.R., Hughes, S.I., Enser, M., Wood, J.D., Richardson, R.I. (2006). Flavour perception of oxidation in beef. Meat Science, 72, 303-311.

Cotton, A.P., Subar, A.F., Friday, J.E., Cook, A. (2004). Dietary sources of nutrients among US adults, 1994 to 1996. Journal of the American Dietetic Association, 104, 921-930.

Cross, A.J., Ferruci, L.M., Risch, A., Graubard, B.I., Ward, M.H., Park, Y. (2010). A large prospective study of meat consumption and colorectal cancer risk: an investigation of potential mechanisms underlying this association. Cancer Research, 70, 2406-2414.

Garbarski, L. (2011). Zachowania nabywców. Polskie Wydawnictwo Ekonomiczne S.A., wyd. 2, Warszawa.

Gdzie Polacy kupują świeżą żywność? Raport Nielsen, marzec 2013. Badanie Nielsen Global Survey dotyczące zakupów świeżej żywności zostało przeprowadzone pomiędzy 10 sierpnia a 7 września 2012 roku. Próba była dobrana pod kątem wieku i płci dla każdego z krajów spośród użytkowników Internetu. Badanie dotyczy zachowań tylko tych respondentów, którzy mają dostęp do Internetu. Internet: http://www.nielsen.com/content/dam/nielsenglobal/eu/nielseninsights/pdfs/Nielsen\%20Global\%20Fresh\%2 0Foods\%20Report\%20March\%202013\%20Poland\%20PL.pdf (dostęp: 02.04.2016).

Górska-Warsewicz, H., Pałaszewska-Reindl, T. (2006). Marki handlowe na rynku produktów żywnościowych. Handel Wewnętrzny, numer specjalny, czerwiec, 341. 


\section{M. Kosicka-Gębska, J. Gębski, K. Kwiecińska, A. Tul-Krzyszczuk, M. Jeznach}

Grunert, K.G., Bredahl, L., Brunso, K. (2004). Consumer perception of meat quality and implications for product development in the meat sector - a review. Meat Science, 66, 259-272.

Guenther, P.M., Jensen, H.H., Batres-Marquez, S.P., Chen, Chun-Fu (2005). Sociodemographic, knowledge, and attitudinal factors related to meat consumption in the United States. Journal of the American Dietetic Association, 2005, 105, 1266-1274.

Gutkowska, K. (2012). Możliwości rozwoju rynku wołowiny w Polsce w kontekście zachowań konsumentów wobec mięsa - odniesienia międzynarodowe, Wydawnictwo SGGW, Warszawa.

Gutkowska, K., Ozimek, I. (2005). Wybrane aspekty zachowań konsumentów na rynku żywności, Wydawnictwo SGGW, Warszawa.

Hoffmann, R. (2000). Country of origin - a consumer perception perspective of fresh meat. British Food Journal, $1,3,211-222$.

Kłosiewicz-Górecka, U. (2013). Struktura handlu detalicznego w Polsce a preferowane przez konsumentów miejsca zakupu FMCG. Konsumpcja i Rozwój, 2(5), 133-145.

Kołożyn-Krajewska, D., Sikora, T. (2004). Towaroznawstwo żywności. Wyd. VI, Wydawnictwo WSiP, Warszawa.

Kosicka-Gębska, M. (2013). Zachowania polskich konsumentów na rynku wołowiny. Wydawnictwo SGGW, Warszawa.

Kosicka-Gębska, M., Tul-Krzyszczuk, A., Gębski, J. (2011). Handel detaliczny żywnością w Polsce. Wydawnictwo SGGW, Warszawa, 90.

Krasnowska, G., Salejda, A. (2011). Ocena wiedzy konsumentów na temat znakowania żywności. Żywność. Nauka. Technologia. Jakość, 74(1),173-189.

Kwasek, M. (2013). Tendencje w spożyciu mięsa na świecie. Roczniki Ekonomiczne Kujawsko-Pomorskiej Szkoły Wyższej w Bydgoszczy, 6, 265-284.

McAfee, A.J., McSorley, E.M., Cuskelly, G.J., Moss, G.W., Wallace, J.M.W., Bonham, M.P., Fearon, A.M. (2010). Red meat consumption: An overview of the risks and benefits. Meat Science, 84, 1-13.

McCarthy, M., de Boer, M., O'Reilly, S., Cotter, L. (2003). Factors influencing intention to purchase beef in the Irish market. Meat Science, 65, 1071-1083.

Niewczas, M. (2013). Kryteria wyboru żywności. Żywność. Nauka. Technologia. Jakość, 6 (91), 204 - 219.

Philipsen, K., Kolind, J. (2012). Supplier and retailer collaboration over the creation of me-too and own brand private labels. Ledelse \& Erhvervsřkonomi, 2, 56.

Rachwał, A. (2006): Cechy chemiczne mięsa drobiowego. Hodowca Drobiu, 2, 28-33.

Radziukiewicz, M. (2012). Zmiany sytuacji dochodowej a wydatki na usługi w polskich gospodarstwach domowych. Konsumpcja i Rozwój, IBRKK, Warszawa, 1 (2),101-107.

Roosen, J., Lusk, J.L., Fox, J.A. (2001). Beef Labeling Strategies in France, Germany, and the UK, American Agricultural Economics, D 120, 1-24.

Rudnicki, L. (2000). Zachowanie konsumentów na rynku. Polskie Wydawnictwo Ekonomiczne., Warszawa, 190198.

Rynek mięsa - stan i perspektywy (2015): Analizy rynkowe, IERiGŻ-PIB, ARR, MRiRW, październik, 63.

Santarelli, R.L., Vendeuvre, J.L., Naud, N., Tache, S., Gueraud, F., Viau, M. i in. (2010). Meat processing and colon carcinogenesis: cooked nitrite-treated and oxidized high-heme cured meat promotes mucin-depleted foci in rats. Cancer Prevention Research, 3, 852-864.

Sepúlveda, W., Maza, M.T., Mantecón, A.R. (2008). Factors that affect and motivate the purchase of qualitylabelled beef in Spain, Meat Science, 80 (4), 1282-1289.

Siriamornpun, S., Wahlqvist, M.L., Mann, N.J., Sinclair, A.J. (2005). Lean meat and heart health. Asia Pacific Journal of Clinical Nutrition, 14, 113-119.

Sklepy specjalistyczne mają się dobrze (2012): Wiadomości Handlowe, 7-8, 20.

Szwacka-Salmonowicz, J. (2003). Zmiany zachowań nabywców jako determinanta kształtowania strategii segmentacyjnych przedsiębiorstw przemysłu spożywczego w Polsce. Iwydawnictwo SGGW, Warszawa.

Szwacka, J. (2006). Uwarunkowania zachowań konsumenckich na rynku żywnościowym w stadium globalizacji. Roczniki Naukowe SERiA, VIII(3), Poznań, 140-145.

Verbeke, W. (2008). Impact of communication on consumers' food choices. Proceedings of the Nutrition Society, 67, 281-288.

Verbeke, W. (2006). Functional foods: consumer willingness to compromise on taste and health. Food Quality and Preference, 17, 126-131

Verbeke, W., Viaene, J. (1999). Ethical challenges for livestock production: meeting consumer concerns about product safety and animal welfare. Paper presented at the First European Congress on Agriculture and Food Ethics, 4-6 March 1999, Wageningen, the Netherlands, 141-151. 
Wezemael, L.V. Ueland, R., Verbeke, W. (2011). European consumer response to packaging technologies for improved beef safety. Meat Science, 89, 45-51.

Zmiany preferencji Polaków w zakresie konsumpcji żywności. Raport GFK na zlecenie Banku BGŻ BNP PARIBAS. Agrokonferencja 2015. Internet: raport_agrokonferencja_2015.pdf (dostęp: 22.03.2016).

Żelazna, K., Kowalczuk, I., Mikuta, B. (2002). Ekonomika konsumpcji elementy teorii. Wydawnictwo SGGW, Warszawa. 